\title{
Şeker Pancarlarında Görülen Rhizoctonia Türlerinin Özellikleri, Oluşturduğu Hastalıklar ve
} Korunma Yolları

\author{
Meltem AVAN"1(iD), Y. Zekai KATIRCIOĞLU \\ ${ }^{1}$ Ankara Üniversitesi Fen Bilimleri Enstitüsü/Ankara \\ ${ }^{2}$ Ankara Üniversitesi Ziraat Fakültesi Bitki Koruma Bölümü/Ankara
}

Öz: İnsanların yaşamlarını sürdürebilmeleri için gerek duyduğu karbonhidratların başında şeker gelmektedir. Şeker pancarı üretimini kısıtlayan birçok faktör bulunmaktadır. Üretimini sınırlayan en önemli faktörlerden biri de şeker pancarında görülen fungal hastalıklardır. Fungal hastalıklar şeker pancarının köklerinde ve yapraklarında enfeksiyon oluşturarak verim kayıplarına neden olmaktadır. Şeker pancarı üretimi yapılan alanlarda kök çürüklükleri birçok tarım alanlarında önemli kısıtlayıcı faktörlerden biri olmuştur. Bunlardan en çok yaygın olanı Rhizoctonia türlerinin neden olduğu hastalık etmenleridir. Bu çalışmada şeker pancarının üretimini sınırlayan Rhizoctonia türlerinin özellikleri, bu türlerin sebep olduğu hastalıklar ve korunma yolları derlenmiştir.

Anahtar Kelimeler: şeker pancarı, Rhizoctonia, hastalıklar, özellikler, korunma yolları

\section{Occurence of Rhizoctonia Species on Sugar Beets, Diseases and Controls}

Abstract: One of the most important carbohydrates that people need to survive is sugar. There are many factors that limit the production of sugar beets. One of the most important factors limiting production is fungal diseases occure on sugar beet. Fungal diseases cause losses by resulting infections in the roots and leaves of sugar beet. In areas where sugar beet is grown, root rot has become one of the most important limiting factors for production in many agricultural areas. The most common of these are root rot caused by Rhizoctonia species. In this study, the characteristics of Rhizoctonia species limiting the production of sugar beet, the diseases caused by these species and ways of protection were reviewed.

Keywords: sugar beet, Rhizoctonia, diseases, occurence, controls

\section{GíRiş}

Şeker pancarı, etli kökünden şeker elde edilen, ıspanakgiller familyasından 2 yıllık kültür bitkisidir. 1. yıl vejetatif, 2. yıl ise generatif organları gelişir ve tohumları birleşik halde bulunur. Boyu $85-180 \mathrm{~cm}$ arasında değişmektedir. Avrupa Birliği, $A B D$ ve Rusya dünya üretiminde ilk üçte bulunur. Ticari ve endüstriyel bir bitkidir. Dünyada şeker üretiminin \%30'u şeker pancarından oluşmaktadır. Türkiye'nin şeker pancarı üretimindeki yeri dünyada 5 . sıradadır.

Dünyada tüketimi yapılan yıllık yaklaşık 143 milyon ton şekerin \%73'ü şeker kamışından, \%27'si ise şeker pancarından oluşmaktadır (Anonim, 2015).

Dünyada 5,8 milyon ha şeker pancarı tarlalarından, 233 milyon ton şeker pancarı üretilmektedir ve ortalama verim 4 ton/da'dır. Türkiye'de ise ekim yapılan 315,344 ha alandan 13,517,241 ton şeker pancarı üretilmekte olup ortalama 4,30 ton/da verim elde edilmektedir. Ülkemiz dünya şeker pancarı üretiminde $\% 5,8^{\prime}$ lik bir paya sahiptir (Anonim, 2013).

Tüik (2015) verilerine göre 15,950,657 ton şeker pancarı üretimi yapılan alanlarda $5,843 \mathrm{~kg} / \mathrm{da}$ pancar verimi, 1,986,916 ton şeker üretimi, 2,390 bin ton şeker tüketildiği bildirilmiştir.

Şeker pancarı üretimi yapılan alanlarda kök çürüklükleri önemli sorunlardan biri olmuştur. Bunlardan en yaygın olanları Rhizoctonia'nın neden olduğu hastalık etmenleridir.
Şeker pancarında taç ve kök çürüklüğüne ve çökertene neden olan etmeni Rhizoctonia solani iken, mor kök çürüklüğüne neden olan etmeni ise Rhizoctonia crocorum'dur. Bu derlemede dünyada ve ülkemizde şeker pancarında sorun oluşturan $R$. solani ve R.crocorum'un genel özellikleri, zarar şekilleri ve korunma yolları hakkında bilgi vermek amaçlanmıştır.

\section{RHIZOCTONIA' NIN GENEL ÖZELLIKLERi}

Rhizoctonia cinsi dünyada ve ülkemizde tespit edilmiş önemli toprak patojenlerinden birisidir. Bu fungus kendi içerisinde çeşitlilik gösterir, geniş ve kompleks bir gruptur (Carling ve ark., 1992).

Çevresel koşullara fazlaca uyumu nedeniyle dünyada yaygınlığı fazladır. Dünyada ekonomik olarak önemli 200 'den fazla bitkide yılda \%20'den fazla ürünün yok olmasına neden olmaktadır (Clarkson ve Cook, 1983; MacNish ve Neate, 1996). Konukçularında; tohum, kök ve sap, meyve çürüklüğü, gövde ve taç kanseri, yaprak ve kın yanıklığı, cüceleşme yaparlar. Fidelerde de çökertene neden olur. Rhizoctonia'ların hastalık oluşturan türlerinin yanında, saprofitik ve mikorizal olanlar ve biyolojik mücadele ajanı olarak kullanılan türleri de yer almaktadır. $R$. solani bir basidiomycete fungusudur. Konidi olarak adlandırılan eşeysiz spor meydana getirmez iken bazı durumlarda basidiospor olarak adlandırılan eşeyli sporlar üretirler.

Sorumlu Yazar: meltemavn@hotmail.com

Geliş Tarihi: 13 Ağustos 2018

Kabul Tarihi: 27 Mayıs 2019 
Miselyum ve skleroti olarak bulunurlar. Septum yapısı oldukça karakteristiktir ve dolipor septum yapısına sahiptir. Fungusun genç hifleri şeffaf ve renksiz iken yaşlandıkça hücre duvarlarındaki melanin birikmesi nedeniyle rengi koyulaşır (Şekil 1 ve 2). Hifler kahverengi, bölmelidir. Hif dalının tabanında bir daralma vardır. Rhizoctonia türlerinin çoğu monilioid hücreler oluştururlar. Bu hücreler genellikle sklerot meydana getirmek için bir araya gelip kümeleşirler.

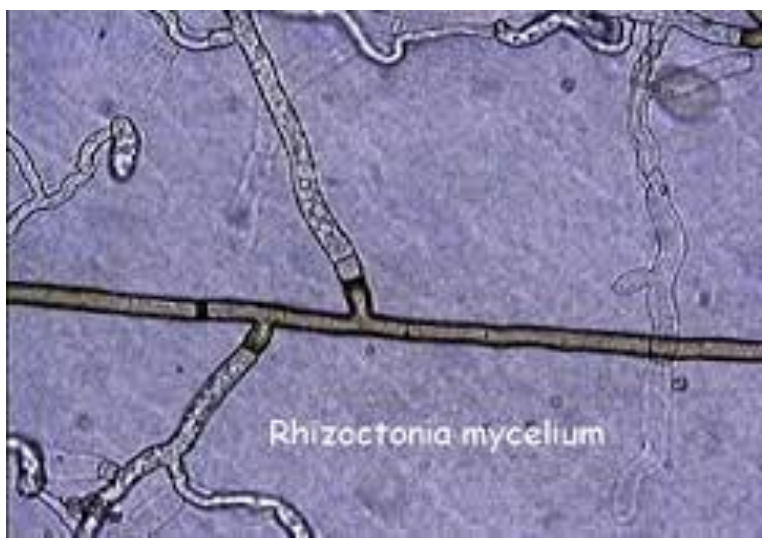

Şekil 1. Rhizoctonia solani'nin olgun hifleri

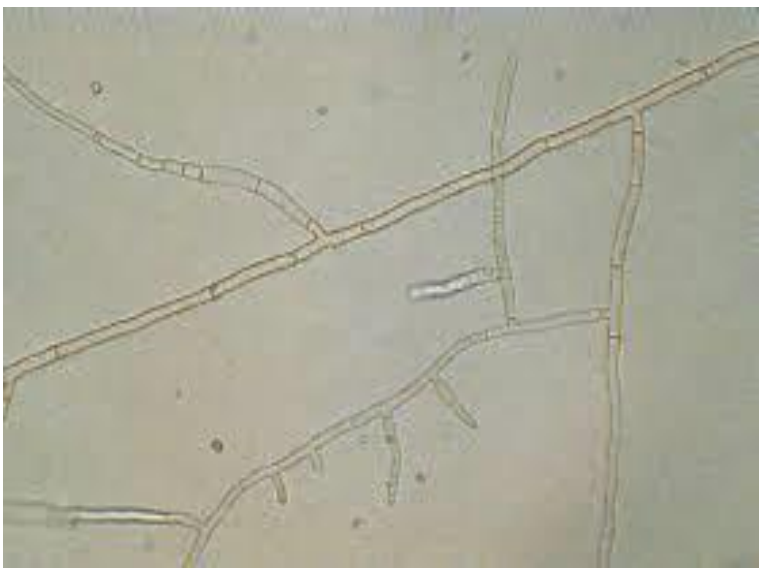

Şekil 2. Rhizoctonia solani hiflerinin 90 derecelik dallanma yapması

Rhizoctonia cinsi, hiflerinde yer alan hücrelerindeki çekirdek sayılarına göre, multinükleat (çok çekirdekli), binükleat (iki çekirdekli) ve uninükleat (bir çekirdekli) olarak üç gruba ayrılmaktadır. Çok çekirdekli ve iki çekirdekli Rhizoctonia grupları içinde hifleri kendi aralarında uyumlu olan ve temas ettikleri yerlerde kaynaşabilen alt gruplar bulunmaktadır ki bunlara anastomosis grup denmektedir (Vilgays ve Cubeta, 1994). Rhizoctonia solani'nin anastomosis grupları AG 1, 2 , $3,4,5,6,7,8,9,10,11,12,13$ ve $A G B 1$ olmak üzere 14 adettir.

\section{İzolasyon}

Konukçu dokusundan- Rhizoctonia'yı konukçudan direkt izole etmek için özel bir yöntem gerekmez. \%70 Etanol'da
30 sn'de 2 da, \%0.5 NaOCl'de 1-2 da yüzey dezenfeksiyonu yapılarak izole edilebilir.

R. solani'yi topraktan izole etmek ve topraktaki yoğunluğunu belirlemek için geliştirilen yöntemler, saprofitik kolonizasyonda tuzak bitkilerin kullanımı, ıslak eleme yapılarak ayrılan bitki artığı parçalarından doğrudan mikroskobik tespit, toprağa daldırılmış plastik tüplerin inkübasyonu, profil tabaka yöntemi, yüzey dezenfeksiyonu yapılan tohumlarda gelişen enfeksiyonlu konukçu dokusundan doğrudan izolasyondur. Son yıllarda da selektif inhibitörlere batırılmış kâğıt disklerin kullanılması ile bir disk-ekim yöntemi çalışılmıştır. Bu diskler alüminyum plakalarda açılan deliklere yapıştırıldıktan sonra bunlar toprağa dikey olarak sokulur.

\section{İzolatların devamlılığı ve saklanması}

İzolatlar laboratuvarda oda sıcaklığında (20-30C), Patates Dekstroz Agar (PDA) içeren test tüplerinde, oda sıcaklığında kurutulmuş PDA'da, doğal bitki materyalleri veya \%4 buğday kepeği toprak karışımında 6-12 ay saklanabilir. Kültürler buzdolaplarında saklanmamalıdır çünkü bazı izolatlar 0-7은 lerde 2-3 ayda canlılığını veya patojenitesini kaybederler. Kültürler, \%3 steril mısır unu-kum, yerfıstığı kapsülleri ve çok sayıda bitki materyallerinde erlenmayerler de geliştirilebilir, doğal olarak kurumaya terk edilir ve oda sıcaklığındaki kabinlerde 12-18 ay saklanabilir.

Rhizoctonia solani dolayısıyla filtre kâğıdı üzerine yerleştirerek, alt kültüre alarak, tahıl taneleri üzerinde, kumda, eğik agarda, agar şeritler üzerinde, mineral yağ altında, silika jel üzerinde, dondurarak kurutma yöntemiyle (liyofilizasyon) saklanabilir (Dikilitaş ve ark., 2011).

Kültürlerin uzun süre canlı olarak saklanması oldukça zordur. $R$. solani kültürleri test tüplerinde mineral yağ altında 7 yıla kadar saklanabilir. Mineral yağ akarların canlı kalmalarını önler. Butler (1980) adlı araştırıcı PDA kültürlerinin $-20{ }^{\circ} C^{\prime}$ de dondurulmuş olarak saklanamadığını ve 16 ay sonra canlılıklarını sürdürmediğini tespit etmiştir. Dolayısıyla izolatları uzun süre saklamak için de yeni bir yöntem tespit etmiştir. Bu yöntemde, kültürler test tüplerinde \%4 buğday kepeği-toprakta geliştirildiklerinde kuru olarak 23-27 어 2 yıl canlı kalmaları sağlanmıştır. Kültürler yaklaşık 1 ay 23-27 ㅇ'de kuruyuncaya kadar geliştirildikten sonra $-25{ }^{\circ} C^{\prime}$ de saklandıklarında birçok kültürler 55 aya kadar canlı kaldıklarını gözlemlemiştir.

\section{Patojenite tespitleri}

Saksı, tava veya tepsilerdeki topraklar otoklav edilmiş toprak, mısır unu-kum, yulaf veya diğer küçük taneli tohumlar ve diğer organik materyallerde geliştirilen $R$. solani ve diğer Rhizoctonia türleri ile bulaştırılabilir. Kök boğazı ve gövde hastalıkları için, bitkiler çıktıktan bir süre sonra inokulum bitki dipleri üzerine veya çevresine dağıtılır ve yüzeysel bir tabaka toprak ile örtülür. Kültürlerden alınan agar parçacıkları doğrudan yaralanmış veya yaralanmamış gövde, kök boğazı ve diğer bitki kısımlarına yerleştirilir.

reticilerin sahte olarak üretilen ürünlerden dolayı haklarının çalınmasını ve tüketicilerin ise kandırılmasını engelleyen bir unsurdur. 
ŞEKER PANCARINDA ÇÖKERTEN TAÇ VE KÖK ÇÜRÜKLÜĞÜ ETMENI RHIZOCTONIA SOLANI

Teleomorph: Thanatephorus cucumeris (Frank) Donk; anamorph: Rhizoctonia solani Kühn

Rhizoctonia solani'nin AG 2-2 IIIB ve AG 2-2 IV anostomosis grupları şeker pancarında hastalık yapmaktadır. AG 2-2 IV AG 2-2 III-B ye göre daha düşük toprak sıcaklıklarında zararlanma yapar (Jacopsen, 2005).

Rhizoctonia solani yıllık ortalama ürünlerde \%2'lik kayba yol açar iken verim kayıplarının \%30-60'ı kolay bir şekilde gözlemlenemez. Tarlanın tamamında ürün kaybı olana kadar bile fark edilemeyebilir. Zamanla tarlada genel olarak solma ve ölüm meydana gelir (Şekil 3 ve 4) (Oliver ve John, 2011)

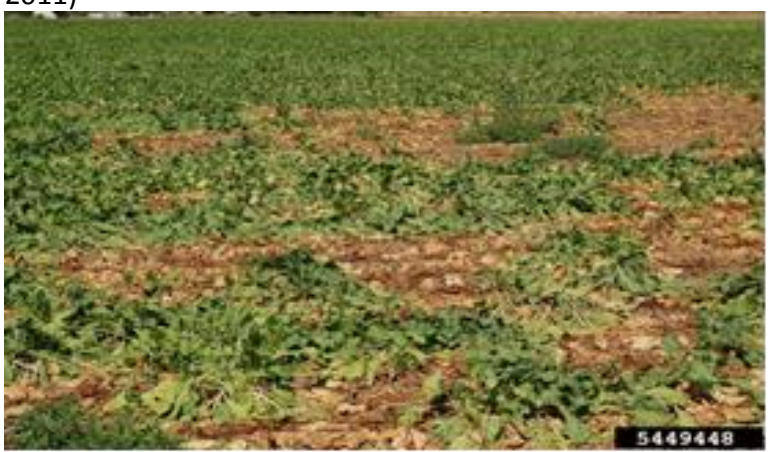

Şekil 3. Şeker pancarı tarlalarında oluşan ürün kayıpları

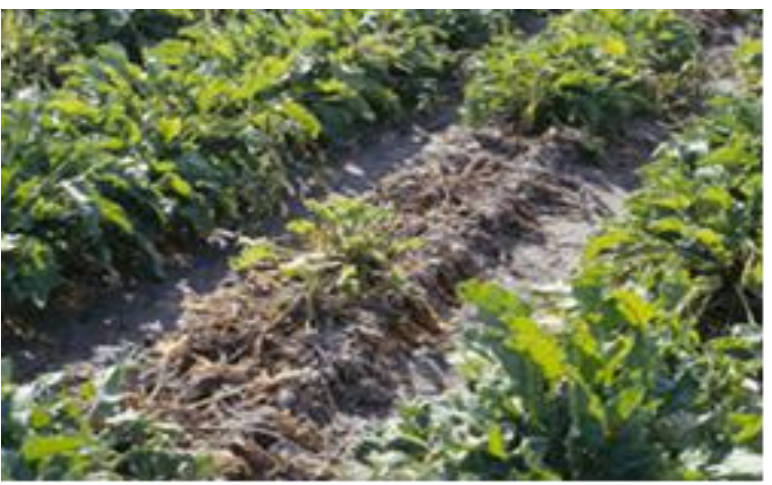

Şekil 4. Hastalıklı şeker pancarı bitkilerinin tarlada yayılışı

Patojenler toprakta skleroti olarak ve organik kalıntılarda miselyum olarak yaşayabilir. Kışlayan propagüller çimlenir ve şeker pancarı taçlarını, yapraklarını ve köklerini enfekte ederek yayılabilir.

\section{Çökerten}

Rhizoctonia solani (AG IV) ile enfekteli fideler suya batırılmış gibi görünür. Dokuda ve toprak yüzeyinin altında kararmalar şeklinde belirti verir ve hipokotile doğru yayılma gösterir. Böylelikle fideler genellikle solar çoğunlukla da ölür (Oliver ve John, 2011).

Verim kayıpları, köklerin kaybından, köklerin bozulmasından dolayı azalan tonaj miktarından ve beyaz şekerin azalmasından kaynaklanmaktadır. Yapraklarda ani ve sürekli solma ve yaprak sapında koyu kahverenginden siyaha renk değişikliği yaparlar (Şekil 5). Zamanla bu renk değişimlerinden sonra bitkide ölüm meydana gelir (Şekil 6) (Harveson, 2008).

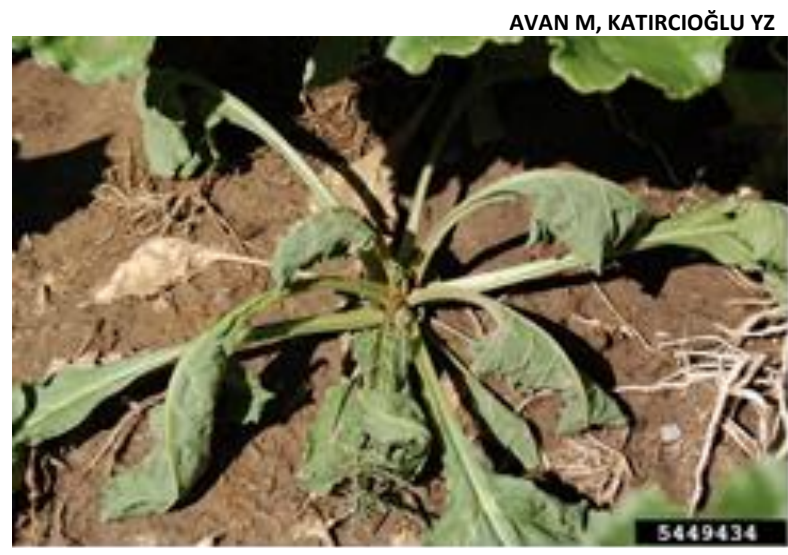

Şekil 5. Rhizoctonia solani enfeksiyonu sonrası bitkide solma

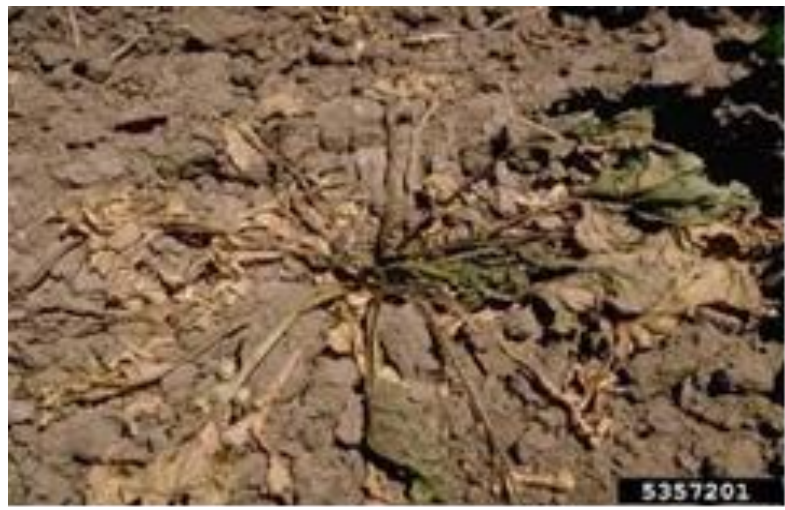

Şekil 6. Rhizoctonia solani enfeksiyonu sonrası bitkide ölüm

\section{Taç ve kök çürüklüğü}

Enfeksiyon taçlarda, şeker pancarı köklerinde veya toprak yüzeyinin altında taç çürüklüğü şeklinde kendini gösterir. Hastalık enfeksiyon noktasından aşağı doğru yayılır. Hastalık ilerledikçe koyu renkli lezyonlar birleşerek dairesel ya da oval lekeler şeklini alır. Rhizoctonia kök çürüklüğü şeker pancarında ani solma yapabildiği gibi kalıcı solma şeklinde de kendini gösterebilir. Yapraklar toprak yüzeyinde çöker ve ölür. Kuru, kırılgan, koyu rozet oluşumu şeklinde taca yapışır kalır (Şekil 7) (Oliver ve John, 2011).

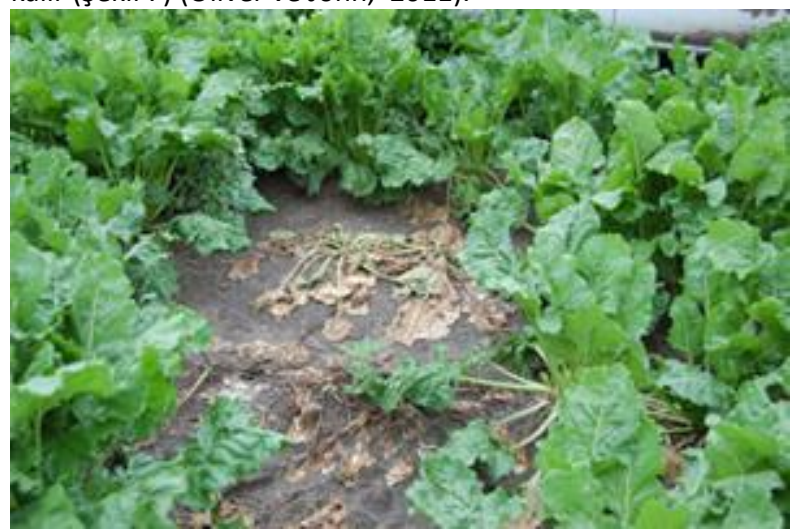

Şekil 7. Şeker pancarında Rhizoctonia solani kök çürüklüğü enfeksiyonu sonrası ani ve kalıcı solma 


\section{Kök belirtileri}

Hastalık şeker pancarı köklerinde koyu kahverengiden siyaha renk değişimine yol açarken bitkide kanserler ve çatlaklar da meydana getirebilir. Bitkide çürüyen kök dokuları katı haldeyken ikincil fungus ve bakteri istilası sonucu yumuşak hale gelebilir. Kök belirtileri genellikle oval şeklindedir, lokalize ve koyu lezyonlar ise dairesel olarak başlar (Şekil 8) (Harveson, 2008).

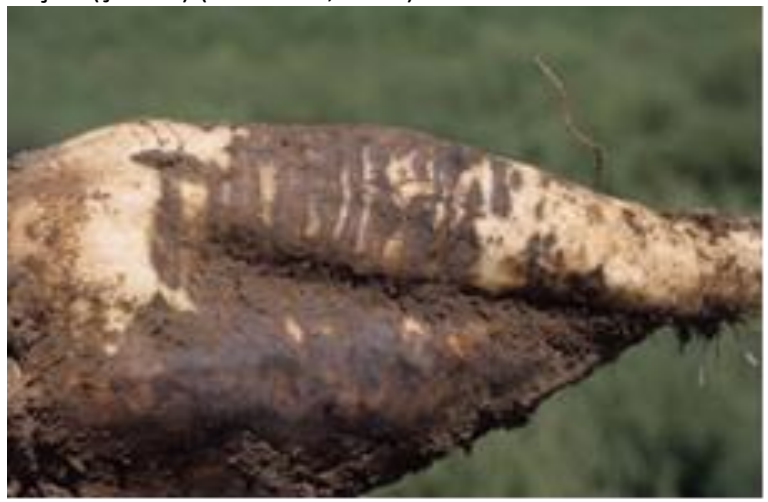

Şekil 8. Rhizoctonia solani enfeksiyonu sonucu merdiven benzeri çürümeler

Illerleyen enfeksiyonlarda lekeler birleşerek merdiven benzeri bir şekil oluşturur (Şekil 9). Kökler kesildiğinde, hastalıklı ve sağlıklı dokular arasında keskin ve belirgin bir çizgi ayrılır. Çürüyen doku genellikle kökün dış kısmında yer alır (Şekil 10) (Harveson, 2008).

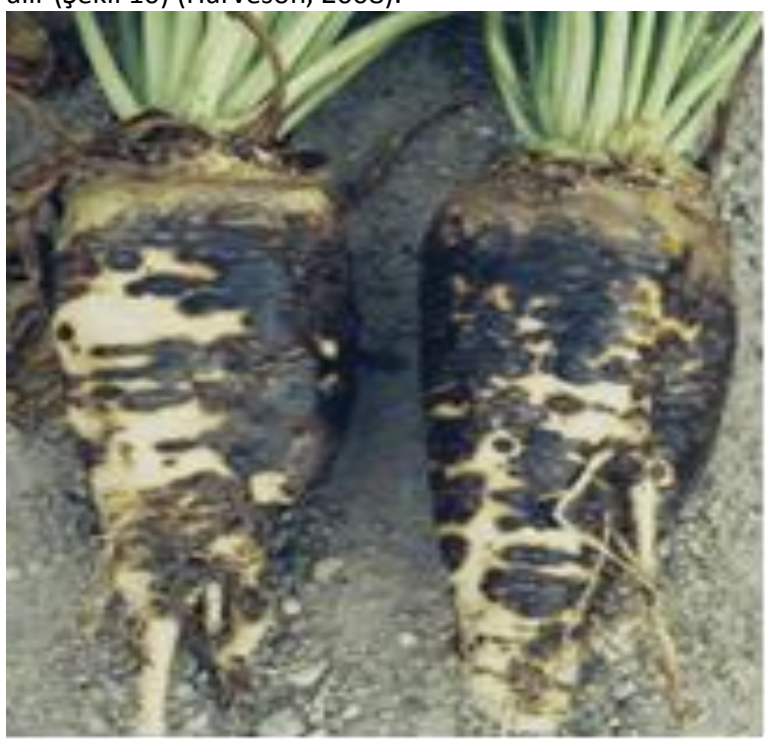

Şekil 9. Rhizoctonia solani enfeksiyonu sonrası oval koyu lezyonlar

Hastalık çok ilerlemedikçe içeriye girmez. ilerleyen enfeksiyonlarda kökleri deforme eden derin çatlaklar veya yarıklar gelişir (Şekil 11). Hastalık kazık köklerde uç çürüme şeklinde belirtiler de meydana getirebilir (Şekil 12). Çürüklük kökten taç kısmına doğru gelişme gösterir (Şekil 13) (Harveson, 2008).

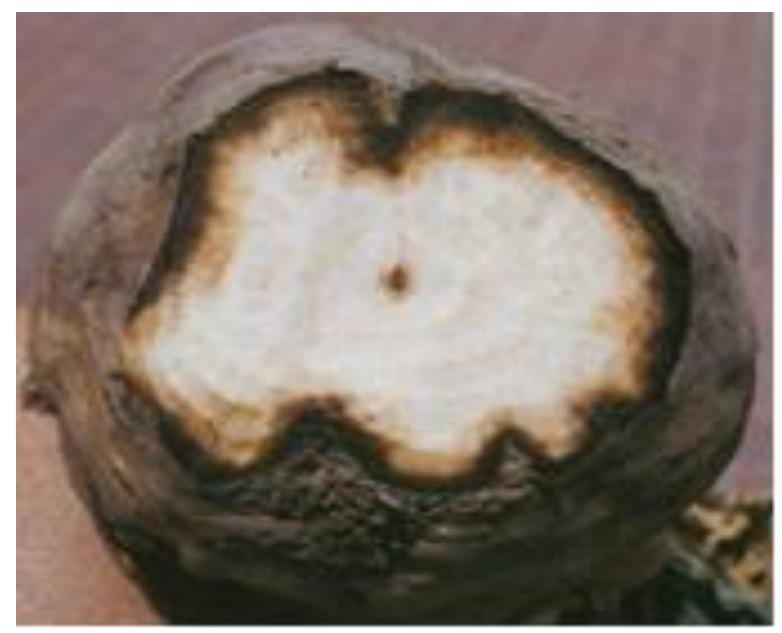

Şekil 10. Rhizoctonia solani enfeksiyonu sonrası şeker pancarı köklerinin kesitlerinde görülen sağlıklı ve hastalıklı doku ayrımı

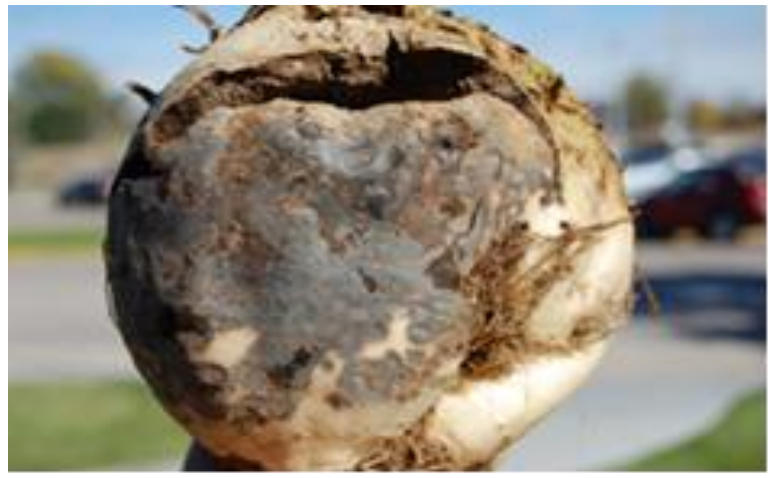

Şekil 11. Rhizoctonia solani enfeksiyonu sonucunda şeker pancarı köklerinde görülen derin yarıklar

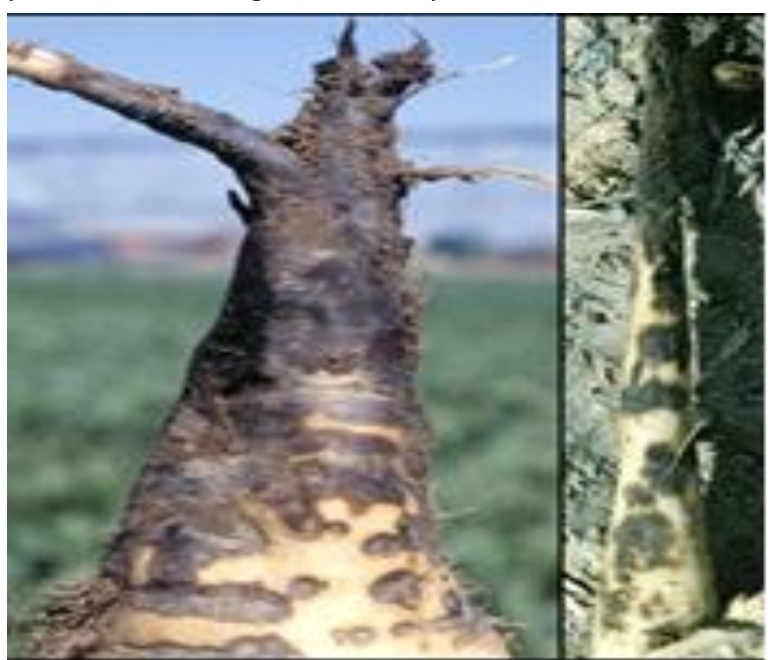

Şekil 12. Rhizoctonia solani enfeksiyonu sonucunda şeker pancarı kazık köklerinde görülen uç çürüme 


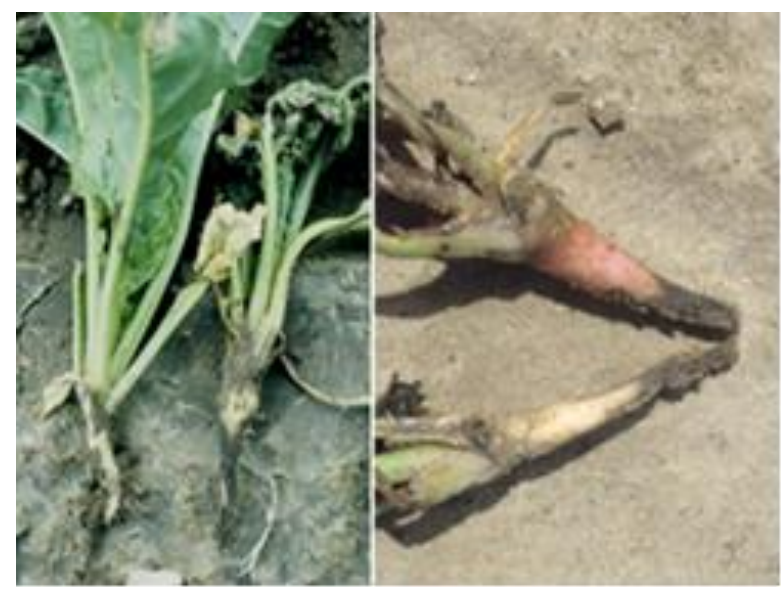

Şekil 13. Rhizoctonia solani enfeksiyonunun kökten taça doğru ilerleyişi

Diğer evre taçtan başlayan enfeksiyonları içerir (Şekil 14). Bu durum genel olarak erken dikimde taç kısımlarına atılan toprakla ilişkilendirilmiştir (Şekil 15) (Harveson, 2008).

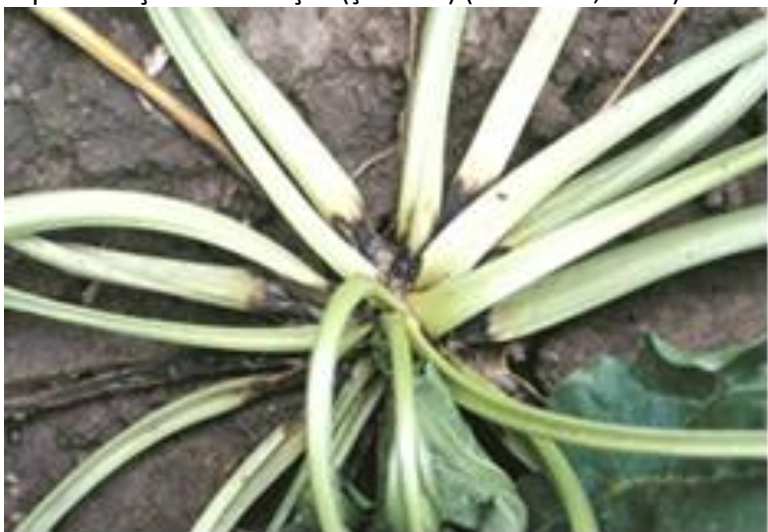

Şekil 14. Rhizoctonia solani enfeksiyonunun taçta yapmış olduğu belirtiler

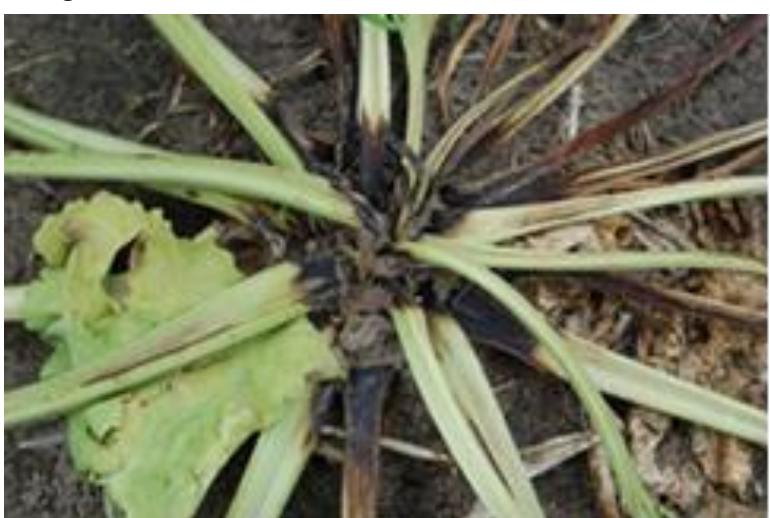

Şekil 15. Erken dikim sonrası taç kısımlarına atılan toprağın yapmış olduğu zarar

Hasat sırasında, yoğun olarak enfekte olmuş kökler tamamen ayrışabilir ve sıralar içinde zeminde delikler bırakılabilir (Şekil 16).

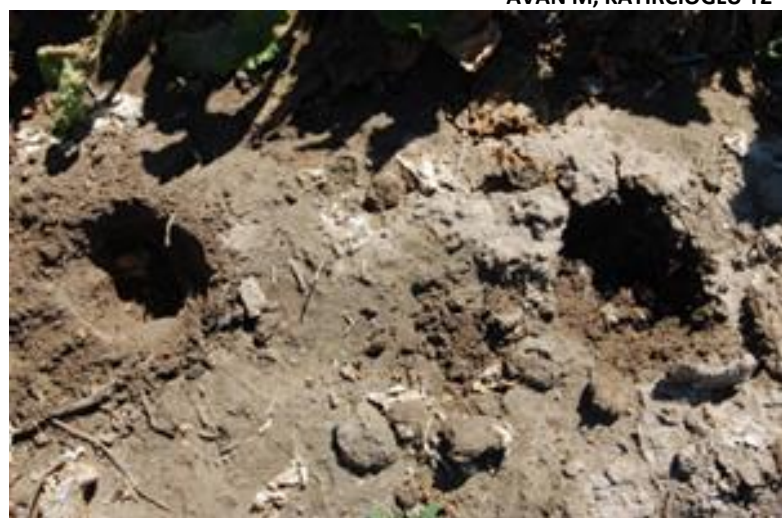

Şekil 16. Hasatta sıralar arasında toprakta oluşan delikler

\section{Yaprak belirtileri}

Hastalık şeker pancarı bitkisinde bodur yaprak gelişimine, donuk yaprak rengine, ani ve kalıcı yaprak solmasına neden olur. Solan dokuda sararma ve öncelikle yaşlı yapraklardan başlayan ölüm şeklinde kendini gösterir. Hastalıklığa yakalanan yaprak sapı zamanla koyu kahverengiden siyaha giden renk alır (Şekil 17). Ölümden sonra yaprak sapları taça bağıı olarak kalır ve ölü yapraklar siyah rozet oluşturur (Şekil 18 ) (Oliver ve John, 2011).

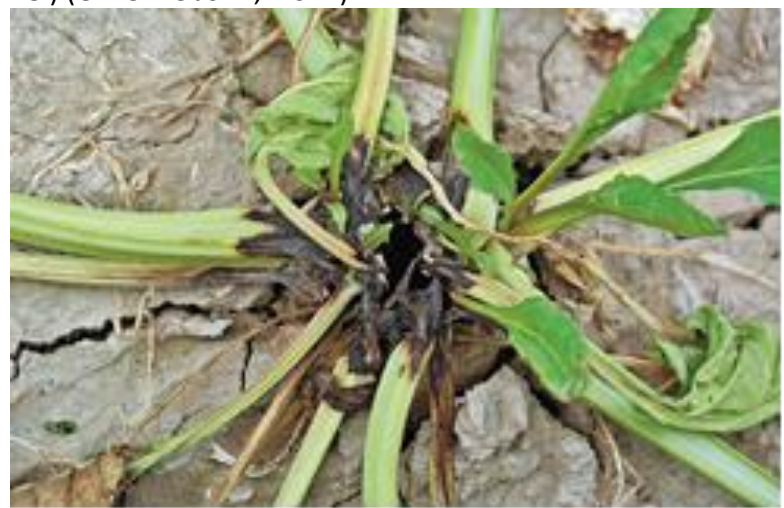

Şekil 17. Rhizoctonia solani ile enfekteli yaprak sapı koyu kahverengiden siyaha doğru değişen renk alması

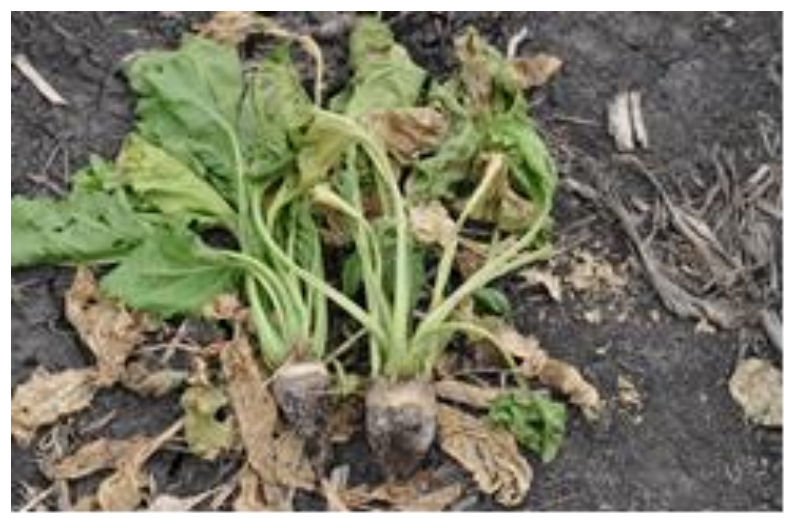

Şekil 18. Rhizoctonia solani enfeksiyonu ile ölüm sonrası yaprak saplarının taça bağlı kalması ve ölü yapraklarda siyah rozet oluşumu 


\section{ŞEKER PANCARINDA MOR KÖK ÇÜRÜKLÜĞÜ ETMENI Rhizoctonia crocorum}

Teleomorph: Helicobasidium purpureum (Tul.) Pat.; anamorph $=$ Rhizoctonia crocorum (Pers.) DC.

Hastalık $A B D$ ve Avrupa'da yoğun olarak gözlemlenmiştir. Hastalık havuç, yonca, kuşkonmaz, soğan, sarımsakta ve şeker pancarının erken dönemlerinde ciddi kayıplara yol açar. Toprak altı bitki parçalarında bulunan mor renkli hif yığınları nedeniyle hastalık, mor Rhizoctonia kök çürüklüğü, kırmızı kök çürüğü, mor kök keçe hastalı̆̆ı veya mor kök çürümesi gibi isimler almıştır (Kiewnick ve ark., 2001).

Hastalık daha çok hafif alkali topraklarda yetişen bitki köklerinde meydana gelir. Şeker pancarında şeker içeriğini azaltır ve şeker pancarının kir tortusunu artırır. $R$. crocorum geniş bir konukçu aralığına sahiptir. Hassas bitkilerin kökleri üzerinde gelişen sklerotilerle hayatta kalırlar. Kazık kök yüzeyinde koyu mor bir lekeye sebebiyet verirler (Şekil 19).
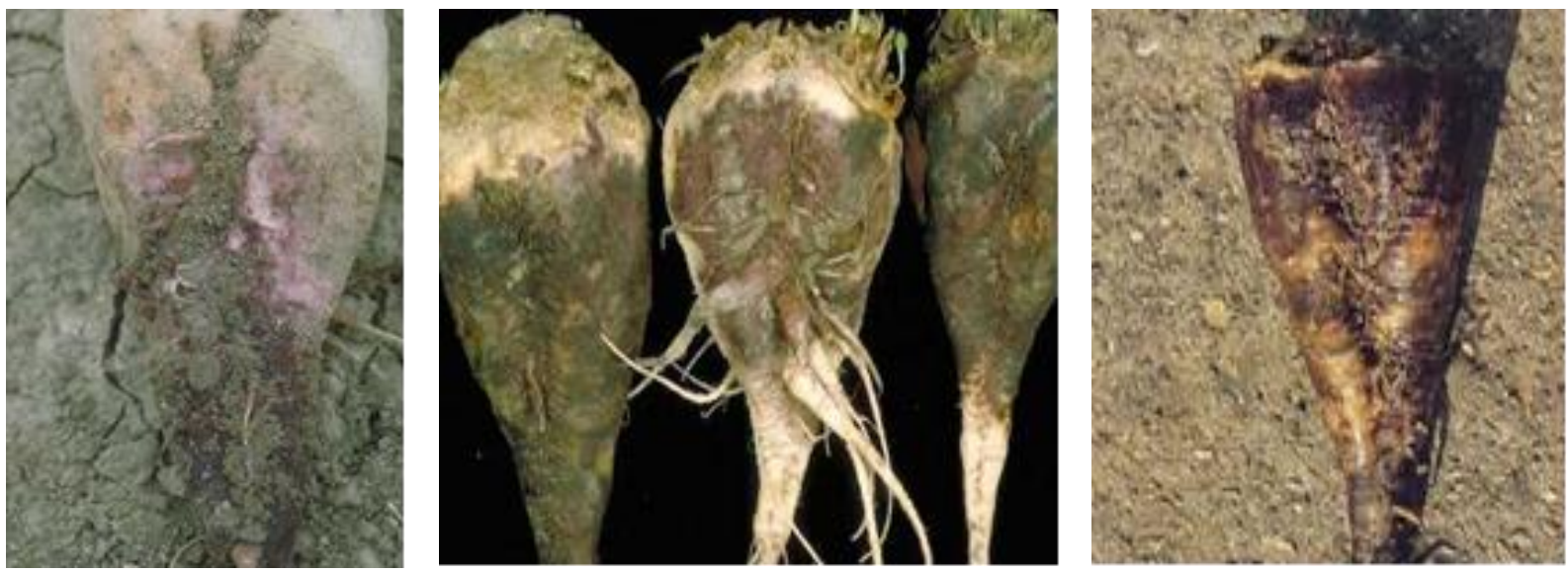

Şekil 19. Rhizoctonia corcorum enfeksiyonu sonrası şeker pancarı köklerinde oluşan mor renkli çürüklük oluşumları

Hastalık genellikle kazık kökün ucundan başlar ve yukarı doğru yayılır. Kökler büzüşür ve kök çevresindeki toprak miktarı artar. En az 4 yıl yaşayabilen sklerotiler genellikle ikincil kökler etrafında bulunur (Kiewnick ve ark., 2001).

\section{KORUNMA YOLLARI}

\section{Rhizoctonia solani için kültürel önlemler}

Rhizoctonia taç ve kök çürüklüğünün az olduğu yerlerde konukçusu olmayan ürünlerle rotasyona gidilebilir. Fakat kısaltılmış rotasyon ya da şeker pancarı monokültürleri hastalıkta ürün kaybının artmasına neden olurlar. Buğday ve arpa gibi ufak daneler kök çürüklüğü etmenini önlemede şeker pancarından önce ekilecek rotasyon için önerilen en önemli ürünlerdir. Ciddi kayıplar fasulye, mısır, patates ve yoncayı takiben görülebilir. Tarlada uzun şeker pancarı rotasyonları olur fakat ağırlıkla fasulye ekilir. $R$. solani AG 22 IIIB veya AG 2-2 IV konukçusu olmayan buğday ve arpa gibi ürünlerle yapılan rotasyonlarda inokulum baskısının düşürülmesine yardımcı olacaktır. Hastalık, nemli koşulları sevdiğinden dolayı toprağı kurutma ve tarla alanlarının tesviyesi hastalığın yönetimine yardımcı olacaktır. Bitki yetiştirme için uygun toprak şartları yaklaşık \%50 katı ve \%50 gözenekli alandan oluşur. Sıkışma oluştururken bu gözeneklerin boyutu ve sayısı azalır, sonuç olarak havalandırma, su geçirgenliği ve drenaj azalmış olur. Toprak sıkışması Rhizoctonia kök çürüklüğü şiddetini ve etkisini büyük oranda artırır. Bu sebeple toprakta meydana gelen sıkışmanın önüne geçilmelidir. Teker izni kontrol ederek, organik madde miktarını artırarak ve derin köklü ürünleri dikerek, yoğun toprak işlemenin azaltılması ile $R$. solani ve diğer kök çürüklüğü patojenlerinin azaltılmasında yüksek oranda başarı sağlanmış olur. Hastalıkla mücadelede yağmurlama ve merkez eksen sulama tercih edilebilir. Bu şekilde sulamalar bitkiye uniform sulama sağlar fakat sık sulamada toprak kurumaya yeterli zaman bulamadığında kök çürüklüğü patojenlerin gelişimini artırır.

Şeker pancarı gelişimi için en uygun toprak nemi toprak matris potansiyeli 40-60 centibars (cbars) arasında olmalıdır. Şeker pancarı aktif kök bölgesinde toprak matris potansiyeli, kumlu toprakta yaklaşık 40 cbars ve alüvyon tınlı toprakta 60-80 cbars olmalıdır. Fakat hem çok ıslak hem kuru topraklar aşırı derecede bitkileri enfeksiyona yatkın hale getirir ve bunlardan kaçınılmalıdır (Oliver ve ark., 2011).

Ürün kalıntıları $R$. solani'nin çoğalması ve hayatta kalmasında önemli bir rol oynar. Bu sebeple tarlada yer alan ürün kalıntıları kaldırılmalı yeni bir enfeksiyona sebep verilmemelidir.

Üreticiler yıllık toprak verimliliği testlerine dayalı, verimlilik tavsiyelerini dikkatlice takip etmelidir. Besinsel stres, eksiklik ya da aşırı beslemede bitkiler enfeksiyona yatkın hale geleceğinden bunlardan kaçınılmalıdır. Aşırı azottan özellikle uzak durulmalıdır.

Uygun ekimde $56 \mathrm{~cm}$ (22 inch) sıra aralığı ile $3048 \mathrm{~cm}$ (100 feet)'lik sıra başına ortalama 150 bitki düşer. Bazı yetiştiriciler daha yakın bitki aralığı ve dar sıralar ile daha iyi sonuçlar elde edebileceklerini düşünmüşlerdir. Bitki 
popülasyonu azaldığında Rhizoctonia solani'nin enfeksiyonu ve kayıp olasılığı artar.

Birkaç yabancı ot türlerinden özellikle karahindiba (Taraxacum spp.), süpürge çiçeği (Kochia scoparia), kazayağı (Chenopodium album), kırmızı köklü tilki kuyruğu (Amaranthus retroflexus L.) ve yabani yulaf (Avena fatua) patojene ev sahipliği yapar. Etkili yabancı ot kontrolü uygulamaları mevsim ve ürün rotasyonu boyunca rotasyonlar önemlidir (Oliver ve ark., 2011).

\section{Rhizoctonia crocorum için kültürel önlemler}

Üreticiler, rotasyon esnasında patojene konukçuluk yapan bitkilerin sıklığını azaltarak, tahıllar ile 4-5 yıl rotasyon yapılmasını uygun görmüşlerdir. Hastalık şiddetini artırmadan erken hasat düşünülmelidir. Bitkinin enfekteli kısımları toplanmalı ve depolanmış yığınlara bulaşmayı engellemek için enfekteli kökler uzaklaştırılmalıdır. Bitki artıkları ve enfekte olmuş bitkileri yakarak veya derine gömerek yok edilmelidir. Toprak asiditesini azaltmalıdır. Dayanıklı konukçu bitki kullanılmalıdır. Erken olgunlaşan çeşitler hastalığa yakalanabileceği için bu çeşitler tercih edilmemelidir.

\section{Rhizoctonia solani için kimyasal mücadele}

Hastalığın kimyasal mücadelesi zordur ve ancak sınırlı alanlarda kısmen başarılı olabilmektedir (Mohammadi ve ark., 2003). Fungisitler (Tolclofos-methyl, Azoxystrobin, Flutolanil, Prothioconazole, Difenoconazole/Propiconazole, Pyraclostrobin, Trifloxystrobin, Pencycuron, Tebuconazole) Rhizoctonia kök çürüklüğü ve fide çökerten kontrolünde kullanılabilir (Kiewnick ve ark., 2001).

Uygulamanın zamanlaması ve metodu hedef olan hastalığın şekline göre değişmektedir. Azoxystrobin, prothioconazole, enfeksiyon meydana gelmeden önce $18 \mathrm{~cm}$ 'lik bir bantta uygulanan bir pyraclostrobin ve fluxapyroxad karışımı etkin hastalık kontrolünü sağlar. $R$. crocorum için kimyasalların kullanımı hakkında hiçbir bilgi yoktur (Oliver ve ark., 2011).

\section{Rhizoctonia solani için biyolojik mücadele}

Rhizoctonia solani'ye karşı çoğunlukla Trichoderma spp., Gliocladium spp., binükleit Rhizoctonia, Pseudomonas spp., Bacillus spp., Streptomyces spp. gibi antagonistlerle daha çok çalışılmaktadır (Trillas ve ark., 2006). Toprak mikroflorası içinde özellikle bitki köklerinde patojen funguslara karşı biyolojik mücadele ajanı olarak ümit veren fungusların başında Trichoderma türlerinin geldiği görülür (Boosalis, Baker ve Cook, 1974, Cook ve Baker, 1983). Trichoderma türlerinin $R$. solani gibi önemli toprak kökenli fitopatojen fungusları kontrol edebilecek düzeyde oldukları, geçmişten günümüze kadar yapılan bazı çalışmalarda açıklanmıştır (Dennis ve Webster, 1971; Chet ve Baker, 1980; Elad ve ark., 1980; Chet ve Baker, 1981; Bell ve ark., 1982).

Faydalı mikroorganizmalar (Trichoderma harzianum, Streptomyces lydicus) $R$. solani'nin şiddetini azalma yeteneğine sahiptir fakat onlar fungisitler kadar etkili değildirler ve kültürel uygulamalar ve tolerant çeşitler ile karışımlarda kullanılmalıdır (Oliver ve ark., 2011).

\section{SONUÇ}

Dünyada şeker üretiminin üçte biri şeker pancarından elde edilmektedir. Ülkemizde de bu ürün geniş ekim alanına sahiptir. Şeker pancarı üretimi yapılan alanlarda kök
AVAN M, KATIRCIOĞLU YZ

çürüklükleri birçok tarım alanlarında önemli kısıtlayıcı faktörlerden biri olmuştur. Bunlardan en yaygın olanlarından biri de Rhizoctonia'nın neden olduğu taç ve kök çürüklükleri, çökertenler ve mor kök çürüklükleridir. Fakat ülkemizde şeker pancarında kök çürüklüğü hastalıkları üzerine sınırlı sayıda çalışma bulunmaktadır. Bu nedenle bu konu üzerinde yapılacak olan çalışmalar önem taşımaktadırlar ve bu çalışmalar ışığında da hastalık ile mücadele yöntemlerinin geliştirilmesi büyük önem arz etmektedir.

\section{KAYNAKLAR}

Anonim (2015) Türkiye İstatistik Kurumu, Tarım İstatistikleri Özeti http://www.tuik.gov.tr Erişim Tarihi: 10.06.2016.

Anonim (2011) Rhizoctonia solani. https://en.wikipedia.org/wiki/Rhizoctonia_solani (Erişim Tarihi: 02.12.2016).

Anonim (2013) Şeker pancarı https://tr.wikipedia.org/wiki/\%C5\%9Eeker_pancar\%C 4\% B1 (Erişim Tarihi: 02.12.2016).

Aydın MH, Turhan G (2009) Rhizoctonia solani'nin Fungal Antagonistlerinin Belirlenmesi Üzerinde Araştırmalar. Anadolu Ege Tarımsal Araştırma Enstitüsü Dergisi, 19(2): 49-72.

Baker KF, Cook RJ (1974) Biological Control of Plant Pathogens. WH Freeman and Company, p. 433-465.

Bell DK, Wells HD, Markham CR (1982) In Vitro Antagonism of Trichoderma Species against Six Fungal Plant Pathogens. Phytopathology, 72(4): 379-382.

Boosalis MG (1964) Hyperparasitism. Annual Review of Phytopathology, 2(1): 363-376.

Butler EE (1980) A method for long-time culture storage of Rhizoctonia solani. Phytopathology, 70(8): 820-821.

Carling DE, Summer DR, Singleton LL, Mihail JD, Rush CM (1992) Methods for Research on Soilborne Phytopathogenic Fungi, APS Press, St. Paul Minnesota. 157-165 p.

Chet I, Baker R (1980) Induction of Suppressiveness to Rhizoctonia solani in Soil Phytopathology, 70(10): 994-998.

Clarkson JDS, Cook RJ (1983) Effect of Sharp Eyespot (Rhizoctonia cereatis) on Yield Loss in Winter Wheat. Plant Pathology, 32(4): 421-428.

Cook RJ, Baker KF (1983) The Nature and Practice of Biological Control of Plant Pathogens. American Phytopathological Society, 539.

Dennis C, Webster J (1971) Antagonistic Properties of Species-Groups of Trichoderma: II. Production of Volatile Antibiotics. Transactions of the British Mycological Society, 57(1): 41-IN4.

Dikilitaş M, Katırcıoğlu YZ, Altınok H (2011) Fungus ve Fungal Materyallerin Uzun Dönem Saklanması, Korunması ve Geri Kazanımı Üzerine Varılan Son Gelişme ve Yöntemler. Harran Üniversitesi Ziraat Fakültesi Dergisi, 15: 55-69.

Edson HA (1915) Seedling Diseases of Sugar Beets and Their Relation to Root Rot and Crown Rot, J. Agric. Research, 4: 135-168. 
Elad Y, Chet I, Katan J (1980) Trichoderma harzianum: A Biocontrol Agent Effective against Sclerotium rolfsii and Rhizoctonia solani. Phytopathology, 70(2): 119121.

Fenille RC, De Souza NL, Kuramae EE (2002) Characterization of Rhizoctonia solani Associated with Soybean in Brazil. European Journal of Plant Pathology 108 (8): 783-792.

Franc GD, Harveson RM, Kerr ED, Jacobsen BJ (2001) Disease management. Sugarbeet Production Guide. University of Nebraska Cooperative Extension EC01156, University of Nebraska, pp. 131-124.

Harveson RM (2008) Rhizoctonia Root and Crown Rot Of Sugar Beet. Univ. Nebr. Ext. Publ G, 1841, April 2008.

Jacopsen BJ (2005) Root Rot Diseases of Sugar Beet 2005. IV International Symposıum on Sugar Beet 26-28 September, 110: 9-19, Novi Sad.

Jacobsen BJ (2006) Root Rot Diseases of Sugar Beet. Proc. Nat. Sci. Matica Srpska, 110: 9-19.

Kiewnick S, Jacobsen BJ, Braun A, KiewnickJL, Eckhoff A, Bergman J (2001) Integrated Control of Rhizoctonia Crown and Root Rot 17 of Sugar Beet with Fungicides and Antagonistic Bacteria, Plant Disease, 85(7): 718722.

MacNish GC, Neate SM(1996) Rhizoctonia Bare Patch of Cereals: An Australian Perspective. Plant Disease, 80(9): 965-971.

Mohammadi M, Banihashemi M, Hedjaroude GA, Rahimian H (2003) Genetic Diversity among Iranian İsolates of Rhizoctonia solani Kühn Anastomosis Group 1 Subgroups Based on Isozyme Analysis and Total
Soluble Protein Pattern. J. Phytopatology, 15: 162170.

Neher OT, Gallian JJ (2011) Rhizoctonia on Sugarbeet: Importance, Identification, and Control in the Northwest. University of Idaho, A Pacific Northwest Extension Publication. November 2011.

O'sullivan E, Kavanagh JA (1991) Characteristics and Pathogenicity of Isolates of Rhizoctonia spp. Associated with Dampingoff of Sugar Beet. Plant pathology 40(1) : 128-135.

Ogoshi A (1987) Ecology and Pathogenicity of Anastomosis and Intraspecific Groups of Rhizoctonia solani Kuhn. Annual review of phytopathology, 25 (1) : 125-143.

Sürel B, Boyraz N. 2009. Şeker Pancarı Silolarında Görülen Fungal Kaynaklı Kök Çürümeleri ve Çürümeleri Etkileyen Bazı Faktörler Üzerine Bir Araştırma. Selçuk Tarım Bilimleri Dergisi, 23(49): 81-87.

Trillas MI, Casanova E, Cotxarrera L, Ordovás J, Borrero C, Avilés M (2006) Composts from Agricultural Waste and The Trichoderma asperellum Strain T-34 Suppress Rhizoctonia solani in Cucumber Seedlings. Biological Control, 39(1): 32-38.

Vilgays R, Cubeta MA (1994) Molecular Systematics and Population Biology of Rhizoctonia. Annu. Rev. Phytopathology, 32: 135-155.

Windels CE, Kuznia RA, Call J (1997) Characterization and Pathogenicity of Thanatephorus cucumeris from Sugar Beet in Minnesota, Plant Disease. 81: 245-249.

Whitney ED, Duffus JE (1986) Compendium of Beet Diseases and Insects. American Phytopathological Society, 76 p. 